\title{
Analisa Perencanaan Penangkal Petir Pada Gedung Kampus Bima Sakti IST Akprind Yogyakarta
}

\author{
Syafriyuddin ${ }^{1}$, M. Suyanto, Subandi, M. Erfan Efendi \\ Jurusan Teknik Elektro, IST AKPRIND Yogyakarta \\ dien@akprind.ac.id ${ }^{1}$,msuyanto@akprind.ac.id², subandi@akprind.ac.id ${ }^{3}$
}

\begin{abstract}
Abstrak - Suatu fenomena alam seperti Petir yang terjadi pada saat atmosfer atas tidak stabil karena adanya konvergensi kolom udara vertikal yang hangat, dengan massa udara di atas yang lebih dingin yang dipanaskan oleh matahari, Arus udara yang naik ini membawa uap air yang, pada saat memenuhi udara dingin, biasanya mengembun, sehingga menimbulkan aktivitas badai konvektif, petir ini dapat menjadi salah satu penyebab alami cedera pada manusia atau kerusakan peralatan listrik Pada perencanaan pemasangan penangkal petir di gedung kampus Bima sakti IST Akprind Yogyakarta menggunakan jenis KURN R80 dengan metode penangkal petir elektrostatis. Untuk kabel penghantar dari ujung sampai pada bak Kontrol menggunakan kabel NYA sedangkan untuk kabel pentanahan menggunkan kabel BC yang terhubung dengan ground root dengan jenis ground root batang yang memiliki panjang $1,5 \mathrm{~m}$ dan diameter $1,5 \mathrm{~cm}$. Dari hasil perhitungan didapatkan nilai tahanan tanah sebesar 4,95 $\Omega$, dan berdasar hasil pengukuran dilapangan mendapatkan hasil 1,16 $\Omega$. Dengan metode ruang nonkonvensional pada gedung kampus Bima sakti IST Akprind Yogyakarta yang tinggi total gedung sampai dengan final 27 meter diperoleh hasil jarak sambaran 130,4 $\mathrm{m}$ dan sudut perlindungan 52,46 dengan radius perlindungan 79,45 $\mathrm{m}$.
\end{abstract}

Kata kunci: Ground Root lightning , Kurn R80, tahanan tanah

\begin{abstract}
A natural phenomenon such as Lightning that occurs when the upper atmosphere is unstable due to the convergence of a column of warm vertical air, with a cooler mass of air above which is heated by the sun, this rising air current carries water vapor which, while filling cold air , usually condenses, causing convective storm activity, this lightning can be one of the natural causes of injury to humans or damage to electrical equipment. In planning the installation of lightning rods in the Bima Sakti IST Akprind Yogyakarta campus building using KURN R80 type with electrostatic lightning rods. For the cable carrying from the end to the control tub using the NYA cable while for grounding cable using $B C$ cable that is connected to the ground root with a type of ground root stem which has a length of $1.5 \mathrm{~m}$ and a diameter of $1.5 \mathrm{~cm}$. From the results of the soil resistance test, get a calculated result of 4,95 $\Omega$, and calculated using a measuring instrument to get a result of $1.16 \Omega$. With the nonconventional space method in IST Akprind Yogyakarta campus building 3, the total building height up to the 27 meter final is obtained $130.4 \mathrm{~m}$ strike distance and $52.46^{\circ}$ protection angle with a $79.45 \mathrm{~m}$ protection radius.
\end{abstract}

Keywords: Ground Root, Kurn R80. Lightning, soil resistance

\section{PENDAHULUAN}

Sistem proteksi petir untuk seluruh area gedung kantor utama dianalisis dengan menggunakan konsep geometri elektrik untuk menentukan sistem proteksi petir untuk mobilisasi pekerja dan kendaraan selama aktivitas mereka di wilayah yang memiliki aktivitas petir tinggi.[15] Ada dua jenis sistem penangkal petir yang dipakai pada bangunan di Malaysia; siatem konvensional dan sistem ikatan struktur, $23 \%$ projek menngunakan sistem ikatan struktur dan 77\% projek menggunakan system konvensional,[9] Perhitungan kekuatan relatif medan listrik di atas batang tajam dan tumpul yang sama menunjukkan bahwa meskipun medan, sebelum emisi apa pun, jauh lebih kuat di ujung batang tajam, dan akan berkurang berdasar jarak [7]

Indonesia yang secara geografis terletak pada garis katulistiwa, menyebabkan Indonesia menjadi negara yang beriklim tropis, hal ini mengakibatkan 
tingginya rata-rata hari guruh dalam satu tahun. dengan metode zona proteksi Razeviq hanya mampu melindungi $11 \%$ daerah perlindungan[4]

Sambaran petir dapat merusak struktur bahan yang terbuat dari kayu, beton, dan bahan logam seperti baja yang bisa mengalirkan arus listrik yang tinggi, dampak kerusakan yang ditimbulkan akan membahayakan manusia dan peralatan berada di dalam gedung tersebut.

Serangan kilat dapat menyebabkan kerusakan struktural yang signifikan pada bangunan. Ini dapat menyebabkan kerusakan pada mesin dan peralatan, baik di dalam maupun di luar gedung dan dapat menyebabkan kerusakan pada orang. Makalah ini menyajikan ulasan tentang prinsip-prinsip proteksi petir dan menetapkan metodologi yang harus diikuti untuk memberikan solusi total untuk efek langsung dan tidak langsung dari sambaran petir.[5]

Dengan jumlah sambaran petir 0,17466 sambaran petir/hari $/ \mathrm{km}^{2}$.hal ini menunjukkan tingkat kebutuhan pengaman gedung-gedung sangat diperlukan terhadap sambaran petir [3]

Sistem pengamanan yang baik perlu dilakukan untuk mengamankan terutama gedung bertingkat dari bahaya sambaran petir yang berupa sistem penangkal petir beserta pentanahannya.

Efektivitas mencegah sambaran petir buatan oleh perangkat proteksi petir ESE lebih unggul daripada perangkat proteksi petir penangkal petir konvensional. Pelepasan Tesla Coil (TC) yang dimodifikasi dengan menyalakan tegangan AC hingga $650 \mathrm{kV}$ dengan generator fungsi pemicu yang dikendalikan digunakan untuk menghasilkan sambaran petir yang disimulasikan.[14]

Oleh karena itu, pada perncanaan pemasangan penangkal petir pada gedung kampus Bimasskti IST Akprind Yogyakrata ini dibutuhkan sebuah alat yang dapat melindungi seluruh bagian gedung dari bahaya sambaran petir.

A. Berdasarkan Peraturan Umum Instalasi Penyalur Petir (PUIPP)

Indonesia adalah salah satu negara yang memiliki frekuensi sambaran yang tertinggi di dunia, hal ini disebabkan karena Indonesia terletak di wilayah ekuatorial yang menerima insolasi yang cukup besar, dan $70 \%$ wilayah Indonesia adalah perairan yang menjadi syarat terbentuknya awan petir. [11]

Sitem pengamanan sambaran petir yang baik harus mampu memberikn perlindungan pada daerah perlndungan nya termasuk bangunan gedung maupun manusia beserta peralatan yang terdapat di dalamnya, terhadap bahaya dan kerusakan akibat sambaran petir.
Berdasarkan Peraturan Umum Instalasi Penyalur Petir (PUIPP) Besarnya kebutuhan tersebut ditentukan berdasarkan penjumlahan.[2],

Indeks-indeks tertentu yang mewakili keadaan bangunan di suatu lokasi dan dituliskan sebagai:

$$
\begin{aligned}
& \mathbf{R}=\mathbf{A}+\mathbf{B}+\mathbf{C}+\mathbf{D}+\mathbf{E} \ldots \ldots \ldots \ldots . . . . . . . \\
& \text { dimana }: \\
& \mathrm{R}=\text { Perkiraan Bahaya Petir } \\
& \mathrm{A}=\text { Penggunaan dan Isi Bangunan } \\
& \mathrm{B}=\text { Konstruksi Bangunan } \\
& \mathrm{C}=\text { Tinggi Bangunan } \\
& \mathrm{D}=\text { Situasi Bangunan } \\
& \mathrm{E}=\text { Pengaruh Kilat }
\end{aligned}
$$

Tabel 1 Jenis Bangunan

\begin{tabular}{|l|c|}
\hline \multicolumn{1}{|c|}{ PENGGUNAAN DAN ISI } & INDEKS $\boldsymbol{A}$ \\
\hline $\begin{array}{l}\text { Bangunan biasa yang tidak perlu } \\
\text { diamankan baik bangunan maupun } \\
\text { isinya }\end{array}$ & -10 \\
\hline $\begin{array}{l}\text { Bangunan dan isinya jarang } \\
\text { digunakan, misalnya dengan di } \\
\text { tengah sawah atau lading, menara } \\
\text { atau tiang dari metal }\end{array}$ & 0 \\
\hline $\begin{array}{l}\text { Bangunan yang berisi perakatan } \\
\text { sehari-hari atau tempat tinggal } \\
\text { misalnya rumah tinggal, industry }\end{array}$ & \\
kecil, dan station kereta api \\
\hline $\begin{array}{l}\text { Bangunan atau isinya yang cukup } \\
\text { penting misalnya menara air, tokoh } \\
\text { barang-barang berharga dan kantor } \\
\text { pemerintahan }\end{array}$ \\
\hline $\begin{array}{l}\text { Bangunan yang berisi banyak sekali } \\
\text { orang misalnya bioskop, sekolah, } \\
\text { sarana ibadah dan monument } \\
\text { bersejarah yang penting }\end{array}$ \\
\hline $\begin{array}{l}\text { Instalasi gas, minyak atau bensin, } \\
\text { dan rumah sakit }\end{array}$ \\
\hline $\begin{array}{l}\text { Bangunan yang mudah meledak dan } \\
\text { dapat menimbulkan bahaya yang } \\
\text { tidak terkendali bagi sekitarnya } \\
\text { misalnya instalasi nuklir. }\end{array}$ \\
\hline
\end{tabular}

Tabel 2 Konstruksi Bangunan

\begin{tabular}{|l|c|}
\hline \multicolumn{1}{|c|}{ KONSTRUKSI BANGUNAN } & INDEKS B \\
\hline $\begin{array}{l}\text { Seluruh bangunan terbuat dari } \\
\text { logam dan mudah menyalurkan } \\
\text { arus listrik }\end{array}$ & 0 \\
\hline $\begin{array}{l}\text { Bangunan dengan konstruksi beton } \\
\text { bertulang atau rangka besi dengan } \\
\text { atap logam }\end{array}$ & 1 \\
\hline $\begin{array}{l}\text { Bangunan dengan konstruksi beton } \\
\text { bertulang atau rangka besi atap } \\
\text { bukan logam }\end{array}$ & 2 \\
\hline $\begin{array}{l}\text { Bangunan kayu dengan atap bukan } \\
\text { logam }\end{array}$ & 3 \\
\hline
\end{tabular}


Tabel 3 Tinggi Bangunan

\begin{tabular}{|c|c|}
\hline Tinggi Bangunan (m) & INDEKS C \\
\hline 6 & 0 \\
\hline 12 & 2 \\
\hline 17 & 3 \\
\hline 25 & 4 \\
\hline 35 & 5 \\
\hline 50 & 6 \\
\hline 75 & 7 \\
\hline 100 & 8 \\
\hline 140 & 9 \\
\hline 200 & 10 \\
\hline
\end{tabular}

Tabel 4 Situasi Bangunan

\begin{tabular}{|c|c|}
\hline Situasi Bangunan & INDEKS D \\
\hline $\begin{array}{l}\text { Di tanah datar pada semua } \\
\text { ketinggian }\end{array}$ & 0 \\
\hline $\begin{array}{l}\text { Di kaki bukit sampai } 3 / 4 \text { tinggi } \\
\text { bukit atau pegunungan sampai } \\
1000 \mathrm{~m}\end{array}$ & 1 \\
\hline $\begin{array}{l}\text { Di puncak gunung atau } \\
\text { pegunungan yang lebih } \\
\text { dari } 1000 \mathrm{~m}\end{array}$ & 2 \\
\hline
\end{tabular}

Tabel 5 Hari Guruh

\begin{tabular}{|c|c|}
\hline Hari Guruh Pertahun & INDEKS E \\
\hline 6 & 0 \\
\hline 12 & 2 \\
\hline 17 & 3 \\
\hline 25 & 4 \\
\hline 35 & 5 \\
\hline 50 & 6 \\
\hline 70 & 7 \\
\hline 100 & 8 \\
\hline
\end{tabular}

Perkiraan bahaya yang di tanggung oleh gedung maupun seluruh peralatan yang berada di dalam nya, maka dilakukan perhitungan dengan mengjitung tingkat resiko yang terjadi, dengan menjumlahkan indeks - indeks tersebut.

Di bawah ini adalah tabel Perkiraan bahaya Sambaran Petir Berdasarkan PUPP.

Tabel 6 Perkiraan Bahaya Sambaran Petir

\begin{tabular}{|c|c|c|}
\hline $\mathbf{R}$ & $\begin{array}{c}\text { Perkiraan } \\
\text { Bahaya }\end{array}$ & Pengamanan \\
\hline Dibawah 11 & Diabaikan & Tidak Perlu \\
\hline $\begin{array}{c}\text { Sama Dengan } \\
11\end{array}$ & Kecil & Tidak Perlu \\
\hline $\begin{array}{c}\text { Sama Dengan } \\
12\end{array}$ & Sedang & Dianjurkan \\
\hline $\begin{array}{c}\text { Sama Dengan } \\
13\end{array}$ & Agak Besar & Dianjurkan \\
\hline $\begin{array}{c}\text { Sama Dengan } \\
14\end{array}$ & Besar & $\begin{array}{c}\text { Sangat } \\
\text { Dianjurkan }\end{array}$ \\
\hline $\begin{array}{c}\text { Lebih Dari 14 } \\
\text { Sangat } \\
\text { Besar }\end{array}$ & Sangat Perlu \\
\hline
\end{tabular}

B. Metode Ruang Proteksi Penangkal Petir

System Rolling Sphere harus di tempatkan di atas struktur, dan juga menyentuh tanah dan sistem terminasi udara. Aplikasi geometris ini memberikan perlindungan di mana sambaran petir langsung tidak dimungkinkan. Semakin tinggi tingkat proteksi terhadap sambaran petir langsung, semakin tinggi batang terminasi udara [13]

Metode ruang proteksi penangkal petir meliputi metode konvensional dan non konvensional akan dijabarkan sebagai berikut :

\section{Metode Ruang Proteksi Konvensional}

Pada awal mula penggunaan nya sistem penangkal petir berbentuk ruang kerucut dengan sudut puncak kerucut berkisar antara 250 hingga 550, semakin besar sudut maka akan semakin tinggi cakupan wilayah pengamanan nya, demikian sebaik nya. [12]

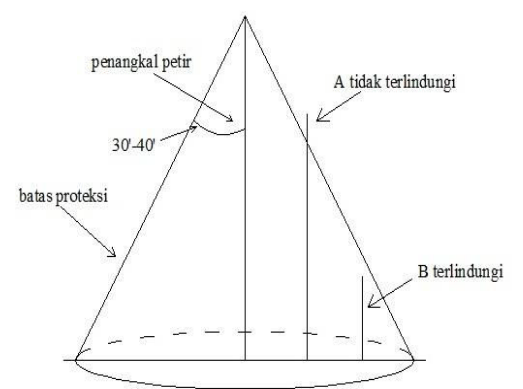

Gambar 1 Realita Dalam Bentuk Tiga Dimensi Ruang

Benda dan peralatan yang berada dalam ruang kerucut adalh daerah yang berada dalam daerah perlindungan dan untuk benda dan peralatan yang berada diluar daerah kerucut adalah daerah yang berada diluar zone perlindungan dari sambaran petir.

Pada penangkal petir konvensional jalur instalasi penyalur petir adalah bersifat pasif menerima sambaran petir. Dan sistem faraday adalah sistem pemasangan penangkal petir yang baik untuk instalasi penangkal petir konvensional.

Perlindungan penghantar seperti ini juga akan berfungsi melindungi gerdung dari bahaya induksi atau masuknya muatan yang besar. Untuk meningkatkan fungsi perlindungan dapat dilakukan dengan menambahkan jumlah konduktor penghantar dan masing-masing konduktor penghantar dihubungkan secara listrik dengan sistem pentanahan. Dalam tes lapangan, batang penghantar dengan ujung bulat telah digunakan sebagai reseptor sambaran yang lebih baik daripada batang berujung tajam di dekatnya [8].

2. Metode Ruang Proteksi Nonkonvensional

Pada teori proteksi non konvensional elektrogeometri hubungan antara sifat listrik dan sifat listrik pada sambaran petir geometri adalah sistem 
perlindungan terhadap petir, teori ini dikembangkan untuk pembuatan elektrogeometri saluran transmisi tegangan tinggi. Model Elektrogeometri didasarkan pada hipotesa sebagai berikut [10] :

- Lidah petir dalam pergerakannya mendekati objek sambaran bumi telah mencapai suatu "titik sambaran" utama, maka petir akan menyambar objek yang terdekat

- Untuk Jarak sambaran petir ditentukan oleh tinggi arus puncak sambaran pertama. Ruang proteksi menurut model elektrogeometri hampir sama dengan ruang proteksi ruang kerucut.[12].

besar arus dan jarak sambaran (rs) dapat di ditunjukkan persamaan berikut [6]:

$$
r_{s}=10 x \mathrm{I}^{(0,65)}
$$

\section{Dimana :}

$$
\begin{aligned}
& \mathrm{rs}=\text { jarak sambaran }(\mathrm{m}) \\
& \mathrm{I}=\operatorname{arus} \text { puncak petir }(\mathrm{kA})
\end{aligned}
$$

Daerah perlindungan dan Sudut perlindungan sebuah penangkal petir dapat kita ditentukan menggunakan rumus empiris dari Hasse dan Wiesinger:

$$
\alpha=\text { are } \sin \left(1-\frac{h}{r_{s}}\right) \ldots \ldots \ldots \ldots \ldots
$$

$$
\begin{aligned}
& \text { Dimana : } \\
& \mathrm{rs}=\text { jarak sambaran }(\mathrm{m}) \\
& \alpha=\text { sudut perlindungan } \\
& \mathrm{h}=\text { tinggi penangkal petir dari atas } \\
& \text { permukaan tanah }
\end{aligned}
$$

Radius daerah perlindungannya ditentukan dengan persamaan berikut [1]

$$
r=\sqrt{2 x r_{s} x h^{2}}
$$

$$
\begin{aligned}
& \text { Dimana : } \\
& \mathrm{h}=\text { tinggi finial di atas tanah } \\
& \mathrm{b}=\text { tinggi bangunan diatas tanah } \\
& \mathrm{rs}=\text { jarak sambar petir }
\end{aligned}
$$

\section{METODOLOGI}

Dalam penelitian ini. Analisis perencanaan system penangkal petir menjadi penting agar daerah perlindungan sambaran petir dapat maksimal. Untuk melihat besarnya nilai tahanan menggunakan alat ukur Digital Earth Resistance Tester 4105 A. Alat ini untuk mengukur nilai tahanan tanah. Elektroda pentanahan dalam penelitian ini mempergunakan elektroda batang (ground rod) dengan diameter 1.5 $\mathrm{mm}$ sepanjang $1.5 \mathrm{~m}$. Ground rod ini ditanam ke dalam tanah secara bertahap dimulai dari kedalaman 5 m sampai kedalaman 25 meter dan setiap kedalaman 5 $\mathrm{m}$ dilakukan pengukuran sampai mendapat hasil yang diingikan.

\section{Kurn R80}

Cara kerja penangkal petir jenis ini yaitu menarik atau menangkap petir yang ada disekitar gedung yang terproteksi oleh penangkal petir KURN R80. Selain harganya murah diantara yang lainnya penangkal petir jenis ini juga berfungsi sesuai apa yang ditawarkan.

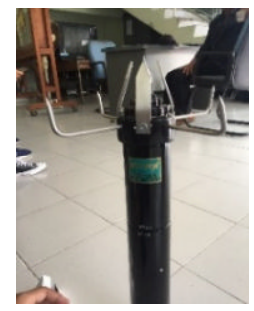

Gambar 2 Penangkal petir KURN R80

Kabel BC

Kabel BC (Bare Copper) merupakan jenis konduktor pelintir telanjang yang berbahan dari tembaga.

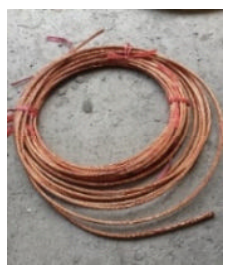

\section{Gambar 3 Kabel BC}

Fungsi dari kabel $\mathrm{BC}$ ini adalah sebagai konduktor penyalur yang langsung terhubung dengan batang pengaman ke tanah. Kabel BC yang digunakan dalam perencaana pemasangan ini yaitu $50 \mathrm{~mm}$ dengan panjang $25 \mathrm{~m}$..

\section{Kabel NYA}

Kabel NYA merupakan kontor pelintir yang dilapisi isolator dengan bahan tembaga. Kabel NYA pada penelitian ini berfungsi sebagai konduktor penyalur dari head chopper ke kabel BC tanpa ada sentuhan ke stuktur logam lain. Ukuran kabel NYA yang digunakan dalam perencaana pemasangan ini yaitu $1 \times 70 \mathrm{~mm}$.

\section{Ground Root}

Ground Root atau elektroda pentanahan berfungsi sebagai penghantar yang ditanam dalam bumi dan membuat kontak langsung dengan bumi. Elektroda pentanahan ini terbuat dari pipa atau besi baja profil yang dipancangkan tegak lurus ke dalam tanah dengan panjang $1,5 \mathrm{~m}$ dan diameter $1,5 \mathrm{~mm}$. 


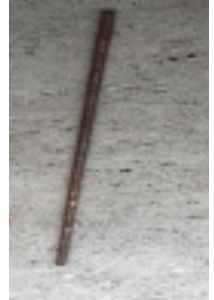

Gambar 4 Ground Root

\section{Pipa Galvanis}

Pipa Galvanis yang digunakan dalam perencaana pemasangan ini terdapat bergai ukuran mulai dari ukuran $1 ; 1,5 ; 2 ; 3$ dim yang fungsinya sama yaitu sebagai tiang head terminal penangkal petir agar mendapatkan level yang tinggi.

Obstruction

Lampu Obstruction lamp berfungsi sebagai penanda letak penangkal petir yang terpasang pada atap gedung.

Analisa

Cara analisis perencaana pemasangan penangkal petir pada kampus bimasakti IST Akprind Yogyakarta

1. Tahap pengeboran tanah. Pengeboran tanah ini dilakukan untuk mengetahui tahanan jenis tanah. Pengeboran tanah ini dengan kedalaman 25 meter.

2. Tahap penanaman ground root yang telah dihubungkan langsung dengan kabel $\mathrm{BC}$.

3. Tahap pengukuran nilai tahanan tanah menggunakan Digital Earth Resistance Teste.

4. Tahap pemasangan penangkal petir. Pemasangan penangkal petir terletak dipuncak tertinggi banguanan dan dihungkan dengan kabel yang telah terhubung dengan ground root di dalam tanah sebagai pembumian.

5. Tahap analisis data yang diperoleh dilapangan akan di analisis dan bandingankan dengan perhitungan rumus.

\section{HASIL DAN PEMBAHASAN}

\section{a. Penentuan Keadaan Bangunan Berdasarkan Peraturan Umum Instalasi Penyalur Petir di Indonesia.}

Berdasarkan Peraturan Umum Instalasi Penyalur Petir di Indonesia ( PUIPP) besarnya nilai pemasangan sistem proteksi terhadap sambaran petir pada suatu bangunan ditentukan dengan menjumlahkan indeskindeks yang mewakili keadaan dilokasi struktur tersebut berada. Maka untuk bangunan tersebut diperoleh indeks sebagai berituk :
1. Jenis bangunan berdasarkan indeks A (table 1) adalah "bangunan atau isinya cukup penting, misalnya menara air, took barang-barang berharga, dan kantor pemerintah" dengan nilai 2 .

2. Jenis bangunan berdasarkan indeks B (table 2) adalah "bangunan dengan konstruksi beton bertulang atau rangka besi dengan atap bukan logam" dengan nilai 2 .

3. Jenis bangunan berdasarkan indeks $\mathrm{C}$ (table 3) adalah "berdasarkan dengan tinggi sampai 25 meter" dengan niali 4.

4. Jenis bangunan berdasarkan indeks D (table 4) adalah "berada ditanah datar pada semua ketinggian dengan niali 0 .

5. Berdasarkan banyak harian guruh sampai 246 hari/tahun, maka nilai untuk indeks E (table 5) adalah 8 .

$$
\begin{aligned}
& \mathbf{R}=\mathbf{A}+\mathbf{B}+\mathbf{C}+\mathbf{D}+\mathbf{E} \\
& \mathbf{R}=\mathbf{2}+\mathbf{2}+\mathbf{4}+\mathbf{0}+\mathbf{8} \\
& \mathbf{R}=\mathbf{1 6}
\end{aligned}
$$

Berdasarkan perhitungan diatas diperoleh hasil $\mathrm{R}$ $=16$ sehingga sesuai dengan tabel 6 nilai tersebut menunjukan bahwa gedung pada kampus Bimasakti IST Akprind Yogyakarta memiliki perkiraan besar bahaya akan sambaran petir dan sangat dianjurkan untuk memiliki sistem proteksi petir yang baik.

\section{b. Perhitungan Resiko Sambaran Petir pada Gedung Kampus Bimasakti IST Akprind :}

\section{Jarak Sambaran Petir}

Besarnya arus puncak petir untuk provinsi D.I. Yogyakarta pada tahun 2018 yakni 51,9771 kA. Sehingga jarak sambaran $\left(r_{s}\right)$ dapat dihitung menggunakan persamaan 2 :

$$
\begin{aligned}
& r_{s}=10 \times \mathrm{N}^{(0,65)} \\
& r_{s}=10 \times 51,9771^{(0,65)} \\
& r_{s}=130,4 \mathrm{~m}
\end{aligned}
$$

Sehingga diperoleh jarak sambaran petir adalah 130,4 meter.

2. Tinggi Finial dan Sudut Perlidungan Penangkal Petir

Perhitungan besar nya sudut perlindungan penangkal petir menggunakan rumus empiris pada persamaan 3. Gedung kampus Bimasakti IST Akprind Yogyakarta mempunyai puncak ketinggian gedung $25 \mathrm{~m}$, ditambah dengan ketinggian finial $2 \mathrm{~m}$, maka ketinggian penangkal petir dari permukaan tanah 27 meter. Maka besarnya sudut perlindungan dapat dihitung :

$$
\alpha=\text { are } \sin \left(1-\frac{h}{r_{s}}\right)
$$




$$
\begin{aligned}
& \alpha=a r e \sin \left(1-\frac{27}{130,4}\right) \\
& \alpha=52,46^{\circ}
\end{aligned}
$$

Besarnya sudut perlindungannya adalah $52,46^{\circ}$

3. Radius Perlidungan Penangkal Petir

Besarnya radius daerah perlindungan (r) penangkal petir yang digunakan dapat dihitung dengan menggunakan persamaan (4) :

$$
\begin{aligned}
& r=\sqrt{\left(2 x r_{s} x h-h^{2}\right)} \\
& r=\sqrt{\left(\left(2 x(130,4) x(27)-27^{2}\right)\right.} \\
& r=79,45 \mathrm{~m} .
\end{aligned}
$$

Berdasarkan hasil perhitungan (r) dari tersebut diperoleh hasil perlindungannya sebesar 79,45m.

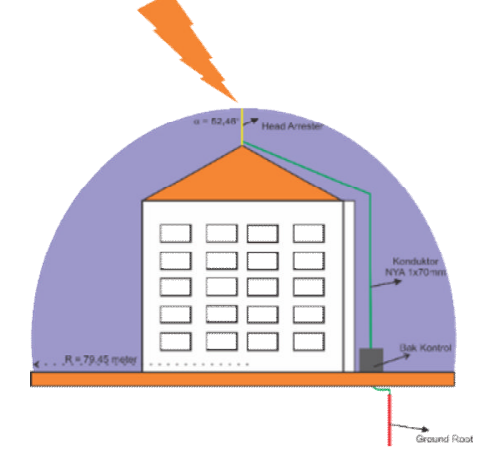

Gambar 5 Radius Perlindungan penangkal petir

\section{c. Pengukuran Tahanan Tanah.}

1. Pengukuran Tahanan Tanah Dengan Alat Ukur

Tabel 7 menunjukkan hasil pengukran nilai tahanan tanah menggunakan alat ukur Digital Earth Resistance Tester :

Tabel 7 Pengukuran tahanan tanah dengan alat ukur

\begin{tabular}{|c|c|}
\hline Kedalaman tanah $(\mathrm{m})$ & Tahanan tanah $(\Omega)$ \\
\hline 5 & 4,57 \\
\hline 10 & 3,01 \\
\hline 15 & 2,26 \\
\hline 20 & 1,49 \\
\hline 25 & 1,16 \\
\hline
\end{tabular}

2. Pengukuran Tahanan Tanah Berdasarkan Rumus.

Pada tabel 8 menunjukkan nilai tahanan tanah berdasar hasil perhitungan, menggunakan rumus
Tabel 8 nilai tahanan tanah hasil perhitungan mengunakan rumus

\begin{tabular}{|c|c|}
\hline Kedalaman Tanah $(\mathrm{m})$ & $\begin{array}{c}\text { Hasil Perhitungan } \\
\text { Berdasarkan Rumus }(\Omega)\end{array}$ \\
\hline 5 & 14,54 \\
\hline 10 & 9,47 \\
\hline 15 & 7,18 \\
\hline 20 & 5,84 \\
\hline 25 & 4,95 \\
\hline
\end{tabular}

\section{d. Perbandingan Hasil Pengukuran Alat Ukur Dengan Perhitungan Dengan Rumus}

Dengan hasil perhitungan rumus yang telah didapat maka data selalnjutnya akan dibandingkan dengan hasil pengukuran dengan alat ukur. Berikut tabel perbandingan hasil ukur tahanan tanah menngunakan alat ukur dengan rumus.

Tabel 9 Tabel Perbandingan hasil pengukuran tahanan tanah menggunakan alat ukur dengan hasil pengukuran tahanan tanah menggunakan rumus

\begin{tabular}{|c|c|c|}
\hline $\begin{array}{c}\text { Kedalaman } \\
\text { Tanah }(\mathrm{m})\end{array}$ & $\begin{array}{c}\text { Hasil Pengukuran } \\
\text { Menggunakan } \\
\text { Alat Ukur }(\Omega)\end{array}$ & $\begin{array}{c}\text { Hasil } \\
\text { Perhitungan } \\
\text { Berdasarkan } \\
\text { Rumus }(\Omega)\end{array}$ \\
\hline 5 & 4,57 & 14,54 \\
\hline 10 & 3,01 & 9,47 \\
\hline 15 & 2,26 & 7,18 \\
\hline 20 & 1,49 & 5,84 \\
\hline 25 & 1,16 & 4,95 \\
\hline
\end{tabular}




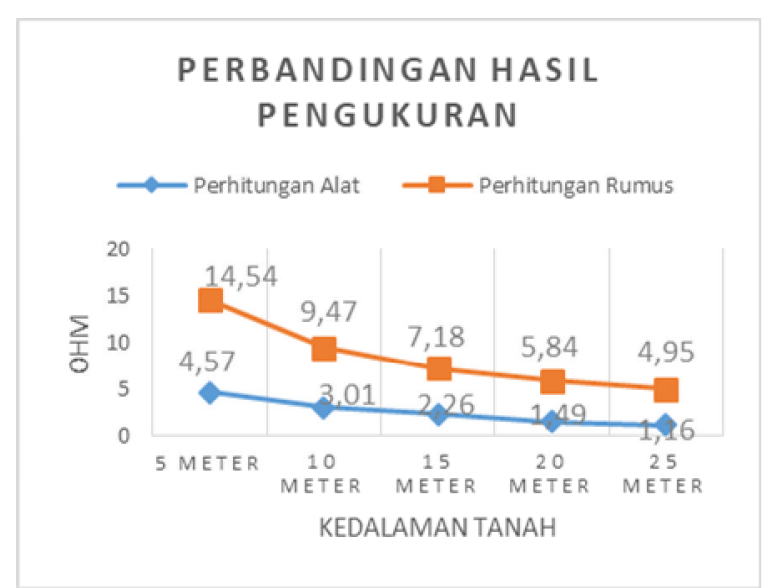

Gambar 6 Grafik perbandingan hasil pengukuran menggunakan alat ukur dengan menggunakan rumus

Pada Gambar 7 menunjukkan bahwa kedalaman tanah mempengaruhi nilai tahanan, semakin dalam pengeboran tanah yang dilakukan maka nilai tahanan tanah akan menurun. Dalam penelitian ini jenis tanah pasir basah sebagai tempat penanaman ground root. di dapatkan hasil perhitungan pada kedalaman $5 \mathrm{~m}$ didapatkan nilai tahanan tanah sebesar 5,16 $\Omega$, dan nilai tahanan berdasar hasil perhitungan sebesar 5,22 $\Omega$. Dan pada kedalaman $25 \mathrm{~m}$ nilai tahanan pentanahan sebesar 1,55 $\Omega$, dan berdasar hasil perhitungan didapatkan nilai tahanan tanah sebesar 1,5 $\Omega$. Sebagaimana ditunjukkan pada tabel 9 .

\section{e. Tegangan Sentuh}

Nilai tegangan yang berada pada suatu objek yang disentuh dan satu titik berjarak satu meter dengan objek yang disentuh dihubungkan dengan sistem pentanahan pumtuk menghitung nilai tegangan sentuh dapat digunakan persamaan berikut:

$$
\begin{aligned}
& E s=I k(R k+1,5 \rho s) \\
& \text { Dimana : } \\
& \text { Es = Tegangan sentuh (Volt) } \\
& \mathrm{Ik}=\text { Arus Fibrasi (Ampere) } \\
& \mathrm{Rk}=\text { Tahanan badan manusia (Ohm) } \\
& \text { Ps = Tahanan jenis tanah pada permukaan tanah } \\
& (\mathrm{Ohm})
\end{aligned}
$$

Berikut hasil perhitungan tegangan sentuh :

Tabel 10. Nilai tegangan sentuh

\begin{tabular}{|c|c|}
\hline $\begin{array}{c}\text { Tahanan Tanah } \\
(\text { Ohm })\end{array}$ & $\begin{array}{c}\text { Tegangan Sentuh } \\
\text { (Volt) }\end{array}$ \\
\hline 4,57 & 4,814 \\
\hline 3,01 & 4,792 \\
\hline 2,26 & 4,782 \\
\hline 1,49 & 4,771 \\
\hline 1,16 & 4,766 \\
\hline
\end{tabular}

Pada tabel 10 di dapat nilai tegangan sentuh yang mengalir pada saluran instalasi penangkal petir masih aman untuk tubuh manusia pada saat terjadi peristiwa petir.

\section{f. Tegangan Langkah}

Suatu nilai Tegangan yang timbul diantara dua kaki yang sedang berdiri diatas permukaan tanah yang sedang dialiri arus yang tidak mengalir ke dalam tanah. Untuk menghitung nilai tegangan langkah digunakan persamaan berikut:

$$
E l=I k(R k+6 \rho s)
$$

Dimana :

$\mathrm{El}=$ Tegangan langkah $($ Volt $)$

$\mathrm{Ik}=$ Arus Fibrasi (Ampere)

$\mathrm{Rk}=$ Tahanan badan manusia $(\mathrm{Ohm}) 500$ $100.000 \mathrm{Ohm}$

Ps $=$ Tahanan jenis tanah pada permukaan tanah (Ohm)

Berikut hasil perhitungan tegangan langkah:

Tabel 11. Nila tegangan langkah

\begin{tabular}{|c|c|}
\hline $\begin{array}{c}\text { Tahanan Tanah } \\
(\mathrm{Ohm})\end{array}$ & $\begin{array}{c}\text { Tegangan Langkah } \\
(\text { Volt })\end{array}$ \\
\hline 4,57 & 5,008 \\
\hline 3,01 & 4,921 \\
\hline 2,26 & 4,878 \\
\hline 1,49 & 4,834 \\
\hline 1,16 & 4,816 \\
\hline
\end{tabular}

Pada tabel 11 di dapat bahwa nilai tegangan sentuh yang mengalir pada tubuh manusia masih relatif aman pada saat terjadi peristiwa petir.

\section{SIMPULAN}

Berdasarkan hasil analisis pada perencaanan penangkal petir dapat diambil kesimpulan sebagai berikut:

1. Dari hasil perhitungan didapatkan nilai $\mathrm{R}=16$, sehingga berdasarkan buku standart PUIPP gedung kampus Bimasakti IST Akprind Yogyakarta termasuk dalam gedung yang mempunyai bahaya besar akan sambaran petir dan sangat dianjurkan untuk memiliki sistem proteksi petir yang baik.

2. System proteksi sambaran petir yang digunakan pada gedung kampus Bimasakti IST Akprind 
Yogyakarta adalah system nonkonvensional, dengan tinggi total gedung sampai dengan final $27 \mathrm{~m}$, diperoleh hasil jarak sambaran $130,4 \mathrm{~m}$ dan sudut perlindungan $52,46^{\circ}$ dengan radius perlindungan $79,45 \mathrm{~m}$.

3. Maka dengan hasil perhitungan tersebut gedung kampus Bimasakti IST Akprind Yogyakarta hanya membutuhkan 1 batang penangkal petir nonkonvensional karena gedung sudah terproteksi seluruhnya.

4. Hasil pengukuran nilai tahanan pentanahan yang telah dilakukan dengan kedalaman 25 meter mempergunakan media tanah pasir basah didapat nilai $1,16 \Omega$, dan berdasar hasil perhtungan didapat nilai $4,95 \Omega$. Hasil ini menunjukan bahwa hasil yang dicapai sudah memenuhi standar sistem pentanahan ketentuan PUIL 2011 yang dimana untuk total seluruh sistem pentanahn tidak boleh melebihi dari $5 \Omega$.

\section{KEPUSTAKAAN}

[1] Anderson., R. V. 2012. Lightning Discharge and Fundamentals of Lightning Protection.

[2] Anonim., 2011. Peraturan Umum Instalasi Penangkal Petir (PUIPP) Untuk Bangunan Indonesia. Jakarta: Direktorat Penyelidikan Masalah Bangunan.

[3] Aris, S. 2017, Perancangan Instalasi Penangkal Petir Eksternal Metoda Franklin Pada Politeknik Enjinering Indorama, Jurnal Sinergi Vol. 21, No. 3, Oktober 2017:219-230

[4] Dadan, A. H. (2010). Optimalisasi Sistem Penangkal Petir Eksternal Menggunakan Jenis Early Streamer (Studi Kasus UPT LAGG BPPT). 37-42.

[5] Kunal, P. 2013, Effect of Lightning on Building and Its Protection Measures, , International Journal of Engineering and Advanced Technology (IJEAT), Volume-2, Issue-6

[6] Lambert R., X. A. (1999). Probability Density Function of the Lightning Crest Current at Ground Level Estimation of the Litghning Strike Incidence on Transmission Line. Budapest: International Confrence on Power System.

[7] MOORE C. B, R. W. 2000. Lightning Rod Improvement Studies, Journal of Applied Meteorology, Volume 39
[8] MOORE, C B, G. D. AULICH, AND WILLIAM RISON, 2003, The Case for Using Blunt-Tipped Lightning Rods as Strike Receptors, Journal of Applied Meteorology, Volume 42

[9] Mustaqqim, Naser A \& Arkam M 2016, Jurnal Teknologi (Sciences \& Engineering) 78:5 (2016) 7-13

[10] Purbomilihung,2008, Lightning buster, www.blogspot .com

[11] Supartono,E.,Haryono T, Suharyanto, 2015. Application of Cone Protection and Rolling Sphere Method in External Lightning Protection Analysis on 214 Radar Tower. International Journal of Advances in Engineering \& Technology, 475-481.

[12] Syakur, A. d. 2006. Sistem Proteksi Penangkal Petir Pada Gedung Widya Puraya.

[13] Tarımer Illhan, Kuca. B.2013, The Proposition to Safety of a Lightning Protection System for High Structures, TEM Journal, 2(4), pp. 309313

[14] Yen-Hong A. Chen, Kai-Jan Lin and Yu-Chu M. Li, 2017, Assesment to Efectivenees of the new early streamer emission lightning protection system, International journal on smart sensing and iteligent systems vol 10 no. 1 march 2017

[15] Zoro, R. (2013). External Lightning Protection System for Main Office Building in the Area with High Lightning Density. Journal Elsevier Procedia Technology 11 (2013) 1238 - 1243 